\title{
Bioactive Cembranoid Composition in the Soft Coral Sarcophyton glaccum on the Response to Changing pH
}

\author{
Hedi Indra Januar ${ }^{1,2}$, Neviaty Putri Zamani ${ }^{2 *}$, Dedi Soedarma ${ }^{2}$, and Ekowati Chasanah ${ }^{1}$ \\ IIndonesian Research and Development Center for Marine and Fisheries \\ Product Competitiveness and Biotechnology, \\ JI. KS Tubun Petamburan VI Slipi, Jakarta Pusat, Indonesia 10260 \\ 2Graduate School of Marine Science, Bogor Agricultural University, \\ JI, Raya Dramaga, Kampus IPB, Bogor, Indonesia 16680 \\ Email: np_zamani@yahoo.com
}

\begin{abstract}
Soft coral is predicted to outcompete with hard coral in future ocean acidification scenarios. Beside the biological resilience shown in acidic conditions, soft corals ability to maintain or compete for space is shown to relate with their ability to produce cytotoxic cembranoid-type compounds. The aim of this study was to investigate composition of cytotoxic cembranoid compounds of Sarcophyton glaccum soft coral exposed to current and predicted future ocean acidification scenarios. S. glaccum colonies were acclimated along a $\mathrm{pH}$ gradient to simulate predicted increases in ocean acidification: natural/current ( $p H$ 8,2), slight increase in acidification ( $p H 8.0$ year-1 2060), and moderate increase in acidification ( $\mathrm{pH} 7,8$ year $^{-1}$ 2100). Cembranoid composition was determined by quantitative Nuclear Magnetic Resonance spectroscopy while cytotoxic activity was determined against tumor cell lines. Results of the study showed cytotoxicity and sarcophytoxide (the most active cembranoid compound in observed S. glaccum) were both found to be higher at $\mathrm{pH}$ 8,0. However, a further increase of acidification resulted on a reduction of both the cytotoxicity and sarcophytoxide production. This suggests that acidification pressures affect directly the defense system metabolism of S. glaccum and that while they may be resilient to small decreases in $\mathrm{pH}$, their ability to compete for space may be hampered by more pronounced changes.
\end{abstract}

Keywords: Cembranoids, cytotoxic, Sarcophyton glaccum, seawater acidification, soft coral

\section{Introduction}

The pressures of ocean acidification, as a direct effect of the increasing anthropogenic greenhouse gas $\mathrm{CO}_{2}$ in the atmosphere, is a major concern for coral reef communities. Numerous experiments have shown a decline in shell and coral skeleton formation of benthic calcifies as seawater $\mathrm{pH}$ decreases (or the dissolved $\mathrm{CO}_{2}$ increases), and is expected to drive a phase shift in coral ecosystems toward domination by algae and non-coral reef-building organisms (Hoegh-Guldberg et al., 2007). The soft coral family Alcyoniidae, is one such benthic organism predicted to expand in coral reef habitats as a result of increasing ocean acidification. A study conducted at $\mathrm{CO}_{2}$ hydrothermal vents on the seashore of Iwotorishima Islands Japan, showed domination by Sarcophytonsp. soft coral as the reef environment became more acidic (Inoue et al., 2013). Growth and calcification processes in soft coral did not change in response to change in acidity or $\mathrm{pCO}_{2}$ levels as the soft coral's external tissue protects the calcified skeleton from dissolution (Gabay et al., 2014; Gomez et al., 2015).
In addition to this biological characteristic, soft coral is also known for its ability to produce allelochemical cytotoxic compounds. Cytotoxicity in soft coral relates to their ability to produce cembranoid-type compounds (a group at terpenoid secondary metabolites). The percent composition of this particular compound class was suggested to be up to $61 \%$ of all of secondary metabolites in soft coral (Rocha et al., 2011). The production of cembranoids correlates ecologically with abiotic and biotic conditions surrounding the soft coral, as a chemical defensive or offensive mechanism from spatial competition, predation, and fouling challenges (Fluery et al., 2004; Hoover et al., 2008; Januar et al., 2011; Chen et al., 2014). The amount of allelochemicals production can be used to predict the degree of soft coral invasiveness in coral reef communities (Lages et al., 2006). Our previous finding showed that cytotoxic activity of extracts of the soft coral Sarcophyton sp. correlated with its cover on natural acidified reefs by $\mathrm{CO}_{2}$ seeps at Mahengetang Islands, Gunung Api Islands, and Minahasa Seashore, Indonesia (Januar et al., 2016). Therefore, the variation in secondary metabolite production may serves as a useful indicator 
of their ability to adapt and survive in future ocean acidification scenarios. This study investigates the effects of increased ocean acidification (using a $\mathrm{CO}_{2}$ gradient) on the cembranoid of soft coral Sarcophyton glaccum, through simulated aquaria-based experiments.

\section{Materials and Methods}

\section{Animal materials}

S. glaccum samples were collected by Scuba from Panggang Island waters, Seribu Islands, Jakarta, Indonesia (S0544.695' E106³5.309'; 3 m depth) on the basis of their morphological similarities according to Fabricius and Alderslade (2001) and Aratake et al. (2012). Random colonies of roughly the same size (10 $\mathrm{cm}$ ) were carefully sampled, placed in a box filled with seawater and aerated (dissolved oxygen level above 7 mg.L-1) on the boat directly above sampling site. Samples were taken to basecamp on Pramuka Island (30 minutes from sampling site) and transferred into an outdoor aquarium covered with a shade roof, to maintain natural daylight. Soft corals were acclimatized over 3 days, with healthy soft coral colonies showing regular daily tentacle extension and feeding activity (Tseng et al., 2001). Soft corals were fed fresh Nauplii of Artemia salina daily at 10:00 and 23.00 hour. Moreover, half of the water was exchanged daily at 08.00-09.00 with natural seawater. Once they were acclimatized, healthy colonies were selected for experimental analysis. All soft corals were transferred in plastic buckets filled with seawater, to avoid/minimize any stress related to exposure to air.

\section{Experimental design}

Three experimental aquariums with 4 healthy colonies of $S$. glaccum at each aquarium were designed in this study. Daily maintenance of each aquarium was conducted as acclimatization previously. Aquarium (1) was the control aquarium (natural $\mathrm{pH}$ at 8.2), aquarium (2) was low acidification ( $\mathrm{pH} 8.0)$, and aquarium (3) was the moderate acidification ( $\mathrm{pH} 7.8$ ). Acidification was achieved by bubbling $\mathrm{CO}_{2}$ gas directly into the aquarium water. The $\mathrm{pH}$ was digitally monitored hourly with a HACH HQ40d-pH probe and where necessary $\mathrm{CO}_{2}$ gas addition adjusted to maintain the target $\mathrm{pH}$. Moreover, dissolved oxygen, temperature, and salinity were analyzed at 10.00, 18.00, and 23.00 hour each day (with three replications) by digital portable devices each day ( $\mathrm{HACH}$ HQ40d with DO probe and Eutech Salt +6 Digital Salt-meter). The lowest $\mathrm{pH}$ of 7.8 level was based on predicted seawater $\mathrm{pH}$ levels in the next century (Gattuso and Lavigne, 2009). Alkalinity of seawater was measured by the method of Lee et al.,
(2006). Furthermore, carbonate chemistry in each aquarium calculated by $\mathrm{CO}_{2} \mathrm{SYS}$ v2.1 software (Pierrot et al., 2006). After three days of exposure to the target $\mathrm{pH}$ condition, $20 \mathrm{~g}$ of samples were taken (12 samples in total for each aquarium, from 3 replicates and 4 colonies), preserved with $20 \mathrm{~mL}$ ethanol, and transported to the laboratory in a cool box on ice.

\section{Analysis of bioactivity and cembranoids composition}

Cembranoid composition, based on the presence of these three compounds (Figure 1), was assessed for each sample. These cembranoids were characterized from our previous study (Iswani et al., 2006). The ethyl acetate fractions were freeze dried and then dissolved in $0,7 \mathrm{~mL} \mathrm{CDCl}_{3}$ spiked with 1 mg.mL ${ }^{-1}$ 1,2,4,5-Tetrachloro-3-nitrobenzene internal standard. 1H-NMR analysis was done on a JEOL ECS $400 \mathrm{MHz}$ spectrometer. The chemical shifts of each diagnostic signal used were: a singlet proton at $\delta 8.52$ (1,2,4,5-Tetrachloro-3-nitrobenzene internal standard), multiplet proton at $\delta 4.05$ (saturated fatty acids), two protons at $\delta 4.43$ (sarcophytoxide), a proton at $\delta 5.75$ (Sarcophytol), and two protons at $\delta 4.75$ (sarcophytolide). Quantification of each compound was done by integration of the internal standard and the diagnostic signal for each compound. The ratio between the amount of total cembranoids (sum of sarcophytoxide, sarcophytol, and sarcophytolide) to saturated fatty acids indicates the "physiological-change indicator" that reflects the relative expenditure of energy on defensive/competitive type compounds relative to energy storage compounds (Fleury et al., 2000). Meanwhile, cytotoxic testing was done based on the 3-(4,5-dimethylthiazol-2-yl)- 2,5- diphenyltetrazolinon bromide (MTT) assay of Zachary (2003). Each ethyl acetate fraction (30 mg. $\mathrm{L}^{-1}$ ) was tested against the T47D and MCF-7 cancer cell lines. A statistical analysis on the ratio of total cembranoids/fatty acids, composition of three cembranoids, and bioactivity of each ethyl acetate fraction, was done using a non-parametric Kruskal-Wallis method in PAST Statistical Software v3.08 (Hammer et al., 2001).

\section{Results and Discussion}

This paper describes the effects of a short-term acidification study on the soft coral $S$. glaccum. It is arguable what the duration of incubation should be to elicit a realistic response from marine organisms and, in particular, soft corals. A wide range of durations are reported in the literature: from 2 hours up to 2 years of incubation in acidic conditions (Hurd et al., 2009). Mostly, longer exposure to acidic conditions was conducted to determine the effect on the skeletal development of key coral reef organisms. In addition, short-term studies (2-7 days) revealed the effects of 


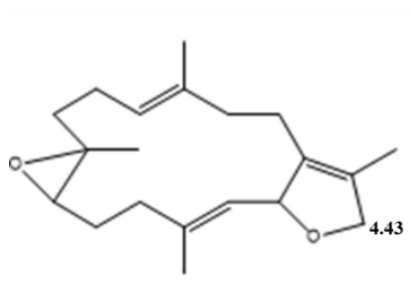

(a)

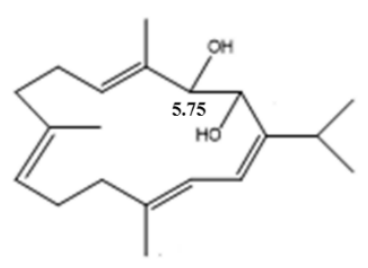

(b)

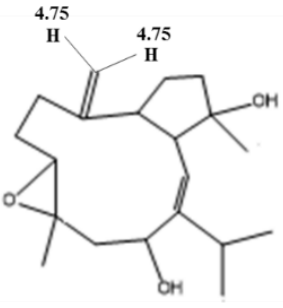

(c)

Figure 1. Targeted cembranoids; sarcophytoxide (a), sarcophytol (b), and sarcophytolide (c), with value in each structure represent $1 \mathrm{H}$ chemical shift that was used in quantitative Nuclear Magnetic Resonance (qNMR) analysis

acidic conditions on metabolic profiles and gene expression in coral reef organisms (Crawley et al., 2010; Fehsenfeld et al., 2011; Nakamura et al., 2011). Indeed, a sensitive species will respond with either a reduced or increased metabolism when exposed acutely to elevated $\mathrm{pCO}_{2}$ (Calosi et al., 2013). As an aside, bioactive secondary metabolite production by soft corals has already shown to be sensitive to different environmental conditions. For example, a significant shift in the metabolic production in the soft coral Lobophytum sp. was detected within 5 days of increased predation (Hoover et al., 2009). These previous findings suggest that a short-term incubation under acidic conditions is appropriate to reveal the shifting patterns in secondary metabolite production from soft coral S. glaccum.

The addition of $\mathrm{CO}_{2}$ gas altered the carbonate chemistry in the seawater of experimental aquariums. Table 1. The values of $\mathrm{CO}_{2}$ partial pressure $\left(\mathrm{pCO}_{2}\right)$, ranging between $211,67 \pm 6,01 \mu \mathrm{atm}$ and $714,17 \pm$ $5,65 \mu$ atm correlated with an increase in the $\mathrm{HCO}_{3}$ acid levels, and as a consequence, decreased the level of saturated aragonite and calcite, both of which are needed by calcifying organisms to grow and synthesize their calcium carbonate skeleton. During the experiment, there was no significant difference in daily tentacle extension from the samples in the $\mathrm{pH} \mathrm{8,0} \mathrm{and}$ 7,8 treatments compared to those in the control aquarium. Tentacles were activated around midnight until dusk and around the middle of the day. Regular daily tentacle extension indicates the soft corals were regularly and actively feeding and hence were healthy (Tseng et al., 2001). The carbonate chemistry analysis also showed that the value of $\Omega$ calcite was higher than for $\Omega$ aragonite. The value of $\Omega$ calcite in the $\mathrm{pH} 7.8$ treatment was found to be similar to $\Omega$ aragonite levels observed in the control aquarium. Similar results were also reported in acidification experiments that were conducted by Gabay et al. (2013) and Gomez et al. (2015). The higher calcite saturation in natural and acidification environments is an advantage to soft coral species. Different from hard coral that uses aragonite, soft coral has the ability to use calcite for its skeleton (Rahman et al., 2011). Therefore, the natural composition of carbonate chemistry under increased ocean acidification conditions is definitely a factor influencing the resilience of soft corals in such conditions.

The assessment of "physiological-change", based on the ratio of total cytotoxic cembranoids to fatty acid content, also indicated there was no significant difference $(P>0.05)$ between the treated samples and the controls (Figure 2). However, the composition of the three cembranoids was determined to be significantly different $(P<0.05)$. The most cytotoxic compound of these, sarcophytoxide, was found by qNMR to be the major cembranoid in all $S$. glaccum samples. The cembranoid ratio in the controls was $60 \%$ sarcophytoxide, $40 \%$ sarcophytol, and trace levels of sarcophytolide. This composition shifted as the $\mathrm{pH}$ decreased from 8,2 to 8,0 and 7,8 . The average of total cembranoids increased, and was driven by an increase in the amount of sarcophytoxide produced (comprising up to $90 \%$ of the total cembranoids). The percent sarcophytolide also increased in samples exposed to $\mathrm{pH} 8,0$. A further increase in acidity $(\mathrm{pH} 7,8)$ resulted in an subsequent return to control levels for sarcophytolide and an overall decrease in the total cembranoid content, although the ratio did not return to control levels, remaining at $90 \%$ sarcophytoxide: $10 \%$ sarcophytol: trace levels of sarcophytolide. Interestingly, both sarcophytoxide and sarcophytol levels were found to be similar between the two treatments $\mathrm{pH} 8,0$ and 7,8 .

The significant difference in variation of cytotoxic cembranoid composition in the treatments corresponded to a significant difference $(P<0.05)$ in the overall cytotoxic activity of the ethyl acetate fractions from each sample (Figure 3 ). This is most likely due to the change in concentration of sarcohytoxide, which is more cytotoxic than the other two cembranoids (Iswani et al., 2014). Therefore, a shift in the ratio of cembranoids will significantly alter the overall cytotoxic activity. A significant increase of cytotoxic activity against both cell lines was found in the samples exposed to $\mathrm{pH} \mathrm{8,0;} \mathrm{this} \mathrm{pattern} \mathrm{mirrored}$ the increase in the percent of sarcophytoxide. 
Furthermore, those samples exposed to $\mathrm{pH} \mathrm{7,8}$ were also more cytotoxic against the MCF-7 and T47D cell lines, again coinciding with the higher percent of sarcophytoxide present in the fraction.

The correlation of elevated cembranoid composition and cytotoxic activity of the soft coral S. glaccum along the $\mathrm{pH}$ gradient may drivea shift in coral community response to increasing ocean acidification levels. It is already documented that the domination of Scleractinian coral will falter under such conditions, but there are many predictions of a variety of organisms which may replace them, such as marine plants, sponges, and soft corals (Hall-Spenceret al.,
2008; Bell et al., 2013; Inoue et al., 2013; Gomez et al., 2015). These organisms, besides their resistance to acidic conditions, also have the ability to produce cytotoxic compounds enabling them to compete successfully for space. This aspect of their chemical ecology may potentially increase their competitiveness in future ocean acidification scenarios (Fleury et al., 2004; Lages et al., 2006). Another study showed that, although sea grass is generally known as the 'winner' with the ability to take advantage of the increasing $\mathrm{CO}_{2}$ levels, its defensive phenolic content decreased under such conditions; this prediction is currently in doubt (Arnold et al., 2012).

Table 1. Carbonate chemistry (average \pm SD) in the experimental aquariums $(n=9)$ derived from C02SYS v2.1 software [17]

\begin{tabular}{cccccccccc}
\hline $\mathrm{pH}$ & $\begin{array}{c}\mathrm{DO} \\
\left(\mathrm{mg} . \mathrm{L}^{-1}\right)\end{array}$ & $\begin{array}{c}\text { Salinity } \\
\left(\mu \mathrm{\mu g} . \mathrm{I}^{-1}\right)\end{array}$ & $\begin{array}{c}\text { Alkalinity } \\
(\mu \mathrm{mol.kg})\end{array}$ & $\begin{array}{c}\mathrm{pCO}_{2} \\
(\mu \mathrm{mtm})\end{array}$ & $\begin{array}{c}\mathrm{HCO}_{3} \\
\left(\mu \mathrm{mol} . \mathrm{kg}^{-1}\right)\end{array}$ & $\begin{array}{c}\mathrm{CO}_{3} \\
\left(\mu \mathrm{mol} . \mathrm{kg}^{-1}\right)\end{array}$ & $\begin{array}{c}\mathrm{CO}_{2} \\
\left(\mu \mathrm{mol} . \mathrm{kg}^{-1}\right)\end{array}$ & $\begin{array}{c}\Omega \\
\text { Aragonite }^{-1}\end{array}$ \\
\hline $8,20 \pm 0,01$ & $7,53 \pm 0,11$ & $32,04 \pm 0,08$ & $2106,12 \pm 5,02$ & $211,67 \pm 6,01$ & $1411,56 \pm 13,60$ & $280,33 \pm 5,51$ & $5,54 \pm 0,19$ & $4,62 \pm 0,10$ & $7,50 \pm 0,15$ \\
$8,00 \pm 0,02$ & $7,61 \pm 0,08$ & $31,96 \pm 0,09$ & $2100,82 \pm 4,56$ & $407,01 \pm 25,33$ & $1624,08 \pm 14,48$ & $193,13 \pm 5,20$ & $10,64 \pm 0,55$ & $3,19 \pm 0,08$ & $5,23 \pm 0,13$ \\
$7,80 \pm 0,04$ & $7,40 \pm 0,21$ & $32,01 \pm 0,08$ & $2103,70 \pm 5,65$ & $714,17 \pm 86,20$ & $1776,35 \pm 34,27$ & $132,91 \pm 12,17$ & $16,68 \pm 2,36$ & $2,19 \pm 0,20$ & $3,62 \pm 0,33$ \\
\hline
\end{tabular}

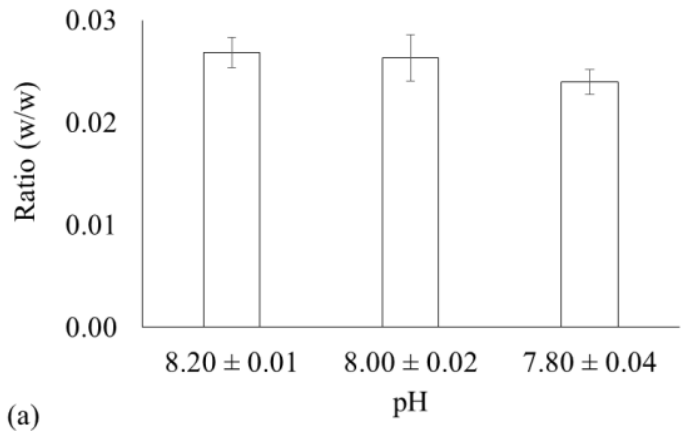

(a)

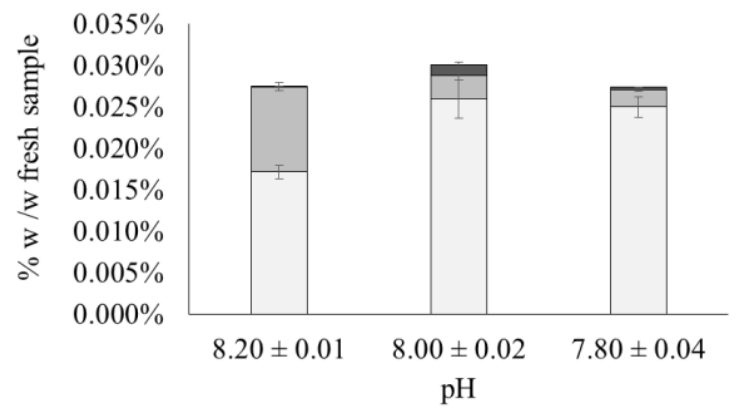

(b) $\square$ Sarcophytoxide $\square$ Sarcophytol $\square$ Sarcophytoxide

Figure 2. Ratio of total cembranoids to saturated fatty acids (a), and composition of cembranoids (\% w/w from fresh sample) in Sarcophyton glaccum (b) that were incubated over 3 days in control ( $\mathrm{pH} 8.2)$, low acidification ( $\mathrm{pH}$. 8.0), and moderate acidification $(\mathrm{pH} 7.8)$, with values represent average $(n=12)$ and error bars represent SD

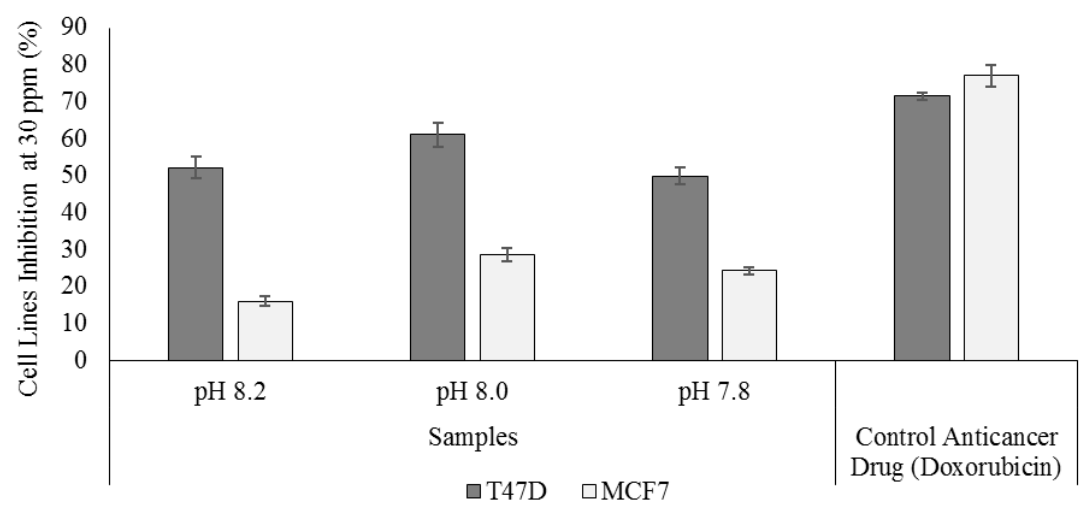

Figure 3. Bioactivity of ethyl acetate fraction from Sarcophyton glaccum that were incubated over 3 days in control ( $\mathrm{pH} 8,2)$, low acidification $(\mathrm{pH} \mathrm{8,0)}$, and moderate acidification $(\mathrm{pH} 7,8)$, with values represent average $(\mathrm{n}=12)$ and error bars represent SD 
Overall, even though biologically several marine benthic organisms have an ability to mitigate destructive effects of increasing ocean acidification, it is highly likely that the organism's metabolism will be adversely affected and thus compromises its competitiveness for benthic space. This study shows that S. glaccum are well placed to take advantage of slight increases in ocean acidification $(\sim \mathrm{pH} 8,0)$ but like other organisms will likely suffer under the predicted 2100 scenario ( pH 7,8).

\section{Conclusions}

The soft coral S. glaccum was found to have a level of biological resistance in mild acidic conditions such that they are likely to dominate coral reefs in the future. However, as their cytotoxic compounds was detected decreased once exposed to the predicted future $\mathrm{pH}$ level of 7,8 , this suggests that acidification pressures affect directly the defense system metabolism of S. glaccum and that while they may be resilient to small decreases in $\mathrm{pH}$, their ability to compete for space may be hampered by more pronounced changes.

\section{Acknowledgments}

This study was financed by Indonesian Research and Development Center for Marine and Fisheries Product Competitiveness and Biotechnology. Our thanks go to Seribu Islands National Parks officers who helped during field research activities. Our acknowledgement also goes to Dr. Cherie Motti, at Australian Institute of Marine Science, for her constructive suggestions in the experiment on this manuscript.

\section{References}

Aratake, S., Tomura, T., Saitoh, S., Yokokura, R., Kawanishi, Y., Shinjo, R., Reimer, J.D., Tanaka, J. \& Maekawa, H., 2012. Soft coral Sarcophyton (Cnidaria: Anthozoa: Octocorallia) species diversity and chemotypes. PLoS One. 7(1): p.e30410. doi: 10.1371/journal.pone.0030410.

Arnold, T., Mealey, C., Leahey, H., Miller, A.W., Hall-Spencer, J.M., Milazzo, M. \& Maers, K., 2012. Ocean acidification and the loss of phenolic substances in marine plants. PLoS one, 7(4), p.e35107.doi:10.1371/journal.pone.0035107.

Bell, J.J., Davy, S.K., Jones, T., Taylor, M.W. \& Webster, N.S., 2013. Could some coral reefs become sponge reefs as our climate changes?. Global change biology. 19(9):2613-2624. doi: 10.1111 /gcb.12212.
Calosi, P., Rastrick, S.P., Lombardi, C., de Guzman, H.J., Davidson, L., Jahnke, M., Giangrande, A., Hardege, J.D., Schulze, A., Spicer, J.I. \& Gambi, M.C. 2013. Adaptation and acclimatization to ocean acidification in marine ectotherms: an in situ transplant experiment with polychaetes at a shallow $\mathrm{CO}_{2}$ vent system. Phil. Trans. R. Soc. $B$, 368(1627):20120444. doi: 10.1098/rstb.2012. 0444.

Chen, M., Shao, C.L., Wang, K.L., Xu, Y., She, Z.G. \& Wang, C.Y. 2014. Dihydroisocoumarin derivatives with antifouling activities from a gorgonianderived Eurotium sp. fungus. Tetrahedron, 70(47):9132-9138. doi: 10.1016/j.tet.2014.08. 055.

Crawley, A., Kline, D.I., Dunn, S., Anthony, K.E.N. \& Dove, S. 2010. The effect of ocean acidification on symbiont photorespiration and productivity in Acropora formosa. Global Change Biology, 16(2), 851-863. doi: 10.1111/j.1365-2486.2009.019 43.x.

Fabricius, K.E. \& Alderslade, P. 2001. Soft corals and sea fans: a comprehensive guide to the tropical shallow water genera of the central west Pacific, the Indian Ocean and the Red Sea. Australian Institute of Marine Science. 264 pp.

Fehsenfeld, S., Kiko, R., Appelhans, Y., Towle, D.W., Zimmer, M. \& Melzner, F. 2011. Effects of elevated seawater $\mathrm{pCO}_{2}$ on gene expression patterns in the gills of the green crab, Carcinus maenas. BMC genomics, 12(1):488. doi: 10.1186/1471-2164-12-488.

Fleury, B.G., Coll, J.C., Tentori, E., Duquesne, S. \& Figueiredo, L., 2000. Effect of nutrient enrichment on the complementary (secondary) metabolite composition of the soft coral Sarcophyton ehrenbergi (Cnidaria: Octocorallia: Alcyonaceae) of the Great Barrier Reef. Mar. Biol., 136(1):63-68. doi: 10.1007/s002270050009.

Fleury, B.G., Coll, J.C., Sammarco, P.W., Tentori, E. \& Duquesne, S., 2004. Complementary (secondary) metabolites in an octocoral competing with a scleractinian coral: effects of varying nutrient regimes. J. exp. Mar. Biol. Ecol., 303(1):115-131. doi: 10.1016/j.jembe.2003.11.006.

Gabay, Y., Benayahu, Y. \& Fine, M., 2013. Does elevated $\mathrm{pCO}_{2}$ affect reef octocorals?. Ecol. and Evol.3(3):465-473.doi: 10.1002/ece3.351.

Gabay, Y., Fine, M., Barkay, Z. \& Benayahu, Y. 2014. Octocoral Tissue Provides Protection from 
Declining Oceanic pH. PloSONE. 9: Article ID e91553. doi: 10.1371/journal.pone.0091553.

Gattuso, J.P. \& Lavigne, H. 2009. Technical note: approaches and software tools to investigate the impact of ocean acidification. Biogeosci. 6: 2121-2133. doi: 10.5194/bg-6-2121-2009.

Gómez, C.E., Paul, V.J., Ritson-Williams, R., Muehllehner, N., Langdon, C. \& Sánchez, J.A. 2015. Responses of the tropical gorgonian coral Eunicea fusca to ocean acidification conditions. Coral Reefs. 34: 451-460. doi: 10.1007/ s00338-014-1241-3.

Hall-Spencer, J.M., Rodolfo-Metalpa, R., Martin, S., Ransome, E., Fine, M., Turner, S.M., Rowley, S.J., Tedesco, D. \& Buia, M.C. 2008. Volcanic carbon dioxide vents show ecosystem effects of ocean acidification. Nature. 454:96-99. doi: 10.1038/ nature07051.

Hammer, O., Harper, D.A.T. \& Ryan, P.D. 2001. Past: Palaeontological Statistics Software package for education and data analysis. Palaeontol. Electron. 4:9pp.

Hoegh-Guldberg, O., Mumby, P.J., Hooten, A.J., Steneck, R.S., Greenfield, P., Gomez, E., Harvell, C.D., Sale, P.F., Edwards, A.J., Caldeira, K. \& Knowlton, N. 2007. Coral reefs under rapid climate change and ocean acidification. Science. 318: 1737-1742. doi: 10.1126/science. 1152509.

Hoover, C.A., Slattery, M., Targett, N.M. \& Marsh, A.G., 2008. Transcriptome and metabolite responses to predation in a South Pacific soft coral. Biol. Bull. 214(3):319-328. doi: 10.2307/25470673.

Hurd, C.L., Hepburn, C.D., Currie, K.I., Raven, J.A. \& Hunter, K.A., 2009. Testing the effects of ocean acidification on algal metabolism: considerations for experimental designs1. J. Phycol. 45(6): 1236-1251. doi: 10.1111/j.1529-8817.2009. 00768.x.

Inoue, S., Kayanne, H., Yamamoto, S. \& Kurihara, H., 2013. Spatial community shift from hard to soft corals in acidified water. Nature Climate Change, 3(7):683-687. doi: 10.1038/nclimate1855.

Iswani, S., Tohir, D. \& Januar, H.I. 2014. Identification of Cytotoxic Compounds in Soft Coral Sarcophyton sp. from Panggang Island Water, Seribu Islands National Parks. Indonesian J. Pharm. Sci. 12:238-243.
Januar, H.I., Hendrarto, B., Chasanah, E. \& Wright, A.D. 2011. Nephthea spp.: correlation between natural products production and pressure from local environmental stressors. J. Mar. Sci. Res. Dev. 8: Article ID 2155-9910. doi: 10.4172/ 2155-9910.s8-001.

Januar, H.I., Zamani, N.P., Soedarma, D. \& Chasanah, E. 2016. Changes in soft coral Sarcophyton sp. abundance and cytotoxicity at volcanic $\mathrm{CO}_{2}$ seeps in Indonesia. AIMS Environ Sci. 3(2):239-248. doi: 10.3934/environsci.2016.2.239.

Lages, B.G., Fleury, B.G., Ferreira, C.E. \& Pereira, R.C., 2006. Chemical defense of an exotic coral as invasion strategy. J. exp. Mar. Biol. Ecol., 328(1):127-135. doi:10.1016/j.jembe.2005.07. 011.

Lee, K., Tong, L.T., Millero, F.J., Sabine, C.L., Dickson, A.G., Goyet, C., Park, G.H., Wanninkhof, R., Feely, R.A. \& Key, R.M., 2006. Global relationships of total alkalinity with salinity and temperature in surface waters of the world's oceans. Geophys. Res. Lett.33(19). doi: 10.1029/2006g|027207.

Nakamura, M., Ohki, S., Suzuki, A. \& Sakai, K., 2011. Coral larvae under ocean acidification: survival, metabolism, and metamorphosis. PLoS One, 6(1): p.e14521. doi: 10.1371/journal.pone.0014521.

Pierrot, D.E., Lewis, E. \& Wallace, D.W.R. 2006. MS Exel Program Developed for $\mathrm{CO}_{2}$ System Calculations. ORNL/CDIAC-105a. Oak Ridge, Tennessee, USA: Carbon Dioxide Information Analysis Centre, Oak Ridge National Laboratory, US Department of Energy.

Rahman, M.A., Oomori, T. \& Wörheide, G. 2011. Calcite formation in soft coral sclerites is determined by a single reactive extracellular protein. J. Biol. Chem. 286:31638-31649. doi: 10.1074/jbc.m109.07 0185.

Rocha, J., Peixe, L., Gomes, N. \& Calado, R. 2011. Cnidarians as a source of new marine bioactive compounds-an overview of the last decade and future steps for bioprospecting. Mar. Drugs. 9:1860-1886. doi: 10.3390/md9101860.

Tseng, L.C., Dahms, H.U., Hsu, N.J. \& Hwang, J.S. 2001. Effects of sedimentation on the gorgonian Subergorgia suberosa (Pallas, 1766). Mar Biol. 158:1301-1310. doi: 10.1007/s00227-0111649-z.

Zachary, I. 2003. Determination of cell number. In: Cell proliferation and apoptosis, D. Hughes and $\mathrm{H}$. Mehmet (Eds). Bios Scientific Publishers. 13-35p. 